Puslitbang Pendidikan Agama dan Keagamaan Badan Litbang Agama dan Diklat Keagamaan, 2003, Cet. III

Priyatno, Drs. Ermawanti, Dasar-dasar Bimbingan dan Konseling, (Jakarta: PT RinekaCipta, 1999), Cet. I

Soebagio Atmodiwirio, Manajemen Pendidikan di Indonesia, (Jakarta: Ardadizya Jaya, 2000)

Syaiful Sagala, Konsep dan Makna Pemeblajaran; untuk Membantu MemecahkanProblematika Belajar dan Mengajar, (Bandung: CV. Alfabet, 2004)

Syaiful Sagala, Administrasi Pendidikan Kontemporer, (Bandung: CV. Alfabet, 2000)

Suharsimi Arikunto, Dasar-dasar Evaluasi Pendidikan, (Yogyakarta: Bumi Aksara, 1995)

Tulus Tu'u, Peran Disiplin terhadap Perilaku dan Prestasi Siswa, (Jakarta: Grasindo, 2004)

Undang-undang RI. No. 20 Tahun 2003, Sistem Pendidikan Nasional dan Penjelasannya, (Bandung: Citra Umbara, 2003)

\section{Konsep-Konsep Dasar Pendidikan Islam Terpadu}

Ridhoul Wahidi, M.A.

Kaprodi ilmu al-Qur'an \& Tafsir Fakultas Ilmu Agama Islam (FIAI) Universtas Islam Indragiri (UNISI) Tembilahan Riau

\section{Abstark}

Pendidikan Islam terpadu merupakan tipe atau model pendidikan yang utuh menyeluruh (syumul), integral, bukan parsial. Konsep-konsep Pendidikan Islam terpadu dibagi menjadi dua aspek besar. Aspek internal meliputi bidang aqidah dan pendidikan hati. Aspek berikutnya adalah eksternal yang meliputi akhlak, jasmani dan rohani, sosial, intelektual, dan seks. Konsep-konsep tersebut menjadi dasar pendidikan Islam terpadu yang kemudian dapat dikembangkan dan dipadukan demi terwujudnya pendidikan yang integral sesuai dengan petunjuk al-Qur'an dan Sunnah Rasul dan tercapainya baldatun

$$
\text { tayyibatun ghofur. }
$$

Key Words: Konsep Dasar, Pendidikan Islam, Terpadu

\section{A. Pendahuluan}

Allah menciptakan manusia sebagai makhluk yang memiliki dua dimensi yaitu dimensi ruhani dan material. Manusia pada sisi materi dituntut agar dapat mempertahankan keberlangsungan hidup di dunia. Pada sisi lain, ia juga dituntut mempertahankan sisi ruhaninya, agar ada keseimbangan, tidak berlebihan pada sisi materi atau sisi ruhaninya. ${ }^{1}$

Untuk menyeimbangkan dua dimensi di atas manusia berusaha untuk melakukan segala hal yang dianggap penting demi menjaga dua dimensi tersebut agar tidak berubah dari fungsinya. Salah satu caranya adalah melalui pendidikan Islam, ${ }^{2}$ yang mana pendidikan ini dapat membantu manusia mengembangkan potensi-potensi yang

1 Kholil al Masawi. Bagaimana Membangun Kepribadian Islam Sejati. (Jakarta : lentera. 2002), hlm. 65

2 Pendidikan Islam diartikan sebagai proses membimbing dan mengarahakan pertumbuhan dan perkerbangan anak didik agar menjadi manusia dewasa sesuai tujuan pendidikan Islam;menanamkan takwa dan akhlak serta menegakkan kebenaran dalam rangka membentak manusia yang berkepribadian dan berbudi luhur menurut ajaran islam. Baca lebih lanjut, M, Arifin. Ilmu Pendidikan Islam;Tinjauan Teoritis dan Praktis Berdasarkan Pendekatan Interdisipliner. (Jakarta: Bumi Aksara. 2003), hlm. 29 
dimilikinya terkondisi secara maksimal.

Disisi lain, agar pendidikan Islam tidak terjebak pada sikap menutup diri, eksklusif yang berakibat ketinggalan zaman atau membu kakan diri dengan resiko dapat kehilangan jati diri atau kepribadian, maka kaum Muslimi harus kembali melihat pada dasar-dasar ajaran nya. Pendidikan Islam dengan begitu harus disandarkan pada telaah filosofis antropologis, yang menjadikan al-Qur'an dan al-Sunnah, Ijma' dan Qiyas sebagai dasarnya.

Pentingnya melihat aspek filosofis antropologis yang berdasar pada sumber hukum Islam ini, dengan pertimbangan karena melihat situasi dan kondisi sosiologis yang sedang mengalami pergeseran nilai pada setiap ruas dan sendi kehidupan manusia, termasuk nilainilai budaya yang mulai tercerabut dari akarnya. Nilai sosial yang banyak terilhami oleh rembesan pergaulan bebas dari dunia Barat lewat berbagai tindakan propagandis, nilai ekonomi yang sudah cenderung pada sistem kapitalis dan bahkan pergeseran nilai-nilai kemanusiaan yang lain.

Pada era globalisasi seperti saat ini para peserta didik menghadapi berbagai masalah global yang membentur dunia masa kini dengan dunia masa depan. ${ }^{3}$ Kehidupan seperti saat ini sangat berpengaruh pada kebiasaan dan sikap peserta didik dalam bidang agama, karena jika sikap peserta didik itu tidak diarahkan dan dikembangkan dalam nilai-nilai yang sesuai dengan ajaran Islam maka akan sangat mustahil peserta didik dapat menyerap ilmu yang didapat dalam jenjang pendidikan sekolah akan diinternalisasikan dalam kehidupan sehari-hari.

Sebenarnya dalam agama Islam telah ada peta konsep dasar pendidikan Islam terpadu, dimana konsep dasar tersebut belum diaplikasikan secara maksimal. Pada tulisan ini, penulis mencoba mengurai konsep-konsep dasar pendidikan Islam terpadu dalam bingkai susunan makalah. Penulis membagi menjadi dua aspek be-

3 Benturan antara dunia masa kini dengan dunia masa depan sekarang ini membawa dampak kepada : (a) kemajuan IPTEK dalam bidang informasi serta inovasi-inovasi baru didalam teknologi yang mempermudah kehidupan manusia, (b) kehidupan masyarakat yang semakin kompetitif, (c) meningkatnya kesadaran terhadap hak-hak asasi manusia serta kewajiban dalam kehidupan bersama Baca lebih lanjut, Fathimah, Psikologi Perkembangan;Perkembangan Peserta Didik. (Bandung : Pustaka Setia, 2006), hlm. 168 sar. Aspek pertama adalah internal, meliputi aqidah dan pendidikan hati. Aspek kedua adalah eksternal, diantaranya akhlak, pendidikan jasmani, pendidikan sosial, pendidikan akal, dan pendidikan seks. Konsep-konsep tersebut dapat diaplikasikan dan dapat diterapkan dalam dunia pendidikan Indonesia sebagai solusi kongkrit demi terwujudnya baldatun tayyibatun wa rabbul ghafur dan sesuai dengan Undang undang dasar Negara ini. ${ }^{4}$

\section{B. Pembahasan}

1. Pengertian Pendidikan Islam

Ada tiga istilah yang umum digunakan dalam pendidikan Islam, yaitu al-tarbiyah, al-ta'lim, dan al-ta'dib. Tarbiyah mengandung arti memelihara, membesarkan dan mendidik yang ke dalamnya sudah termasuk makna mengajar atau 'allama-yu'allimu. ${ }^{5}$ Berangkat dari pengertian ini tarbiyah ${ }^{6}$ didefinisikan sebagai proses bimbingan terhadap potensi manusia (jasmani, ruh dan akal) secara maksimal agar dapat menjadi bekal dalam menghadapi kehidupan dan masa depan. Ta'lim mengandung arti pengajaran yaitu mencerdaskan otak manusia. At-ta'dib mengandung arti pendidikan yang bersifat khusus yaitu memperluas adab kesopanan dan mempertinggi akhlak.

Ahmad Tafsir mengartikan pendidikan Islam dengan

4 Bangsa Indonesia telah merdeka 68 tahun yang lalu (1945-2013). Citacita dan tujuan para pendiri bangsa ini tidak hanya merdeka dari penjajahan fisik tapi merdeka dari kebodohan. Untuk merealisasikan hal tersebut, para pendahulu Negara ini mencantumkan tentang pentingnya mencerdaskan bangsa ke dalam Undang undang dasar Negara Republik Indonesia tahun 1945 pada alenia ke empat,

"Kemudian daripada itu untuk membentuk suatu Pemerintahan Negara Indonesia yang melindungi segenap bangsa Indonesia dan seluruh tumpah darah Indonesia dan untuk memajukan Kesejahteraan umum, mencerdaskan kehidupan bangsa dan ikut melaksanakan ketertiban dunia...”.

5 Ahmad Tafsir. Ilmu Pendidikan dalam Perspektif Islam. (Bandung: Remaja Rosdakarya, cet.5), hlm. 109

6 Tarbiyah dari kata Rabb atau Rabba mengacu kepada Allah sebagai Rabb al alamin. Hal ini dapat mengandung pengertian bahwa terdiri dari empat unsur. Pertama, menjaga dan memelihara fitrah anak menjelang dewasa (baligh); Kedua, mengembangkan seluruh potensi; Ketiga, mengarahkan seluruh fitrah dan potensi menuju kesempurnaan; dan Keempat, dilaksanakan secara bertahap. 
bimbingan yang diberikan oleh seseorang agar ia berkembang secara maksimal sesuai ajaran Islam. Dengan kata lain, pendidikan Islam menurutnya adalah bimbingan terhadap seseorang agar ia menjadi muslim secara maksimal (kaffah).

\section{Pengertian Pendidikan Islam Terpadu}

Istilah "terpadu" dalam sistem pendidikan dimaksudkan sebagai penguat bagi Islam itu sendiri. Maksudnya, Islam yang utuh menyeluruh (kaffah) integral bukan parsial. Artinya pendidikan tidak hanya berorientasi pada satu aspek saja. Sistem pendidikan yang ada harus memadukan unsur pembentukan sistem pendidikan yang unggul.

Islam memandang pendidikan sebagai sesuatu yang identik dan tidak terpisahkan dari asal mula penciptaan manusia. Manusia itu sendiri yaitu jasad, ruh, intelektualitas. Dengan demikian, pendidikan dalam pandangan Islam meliputi tiga aspek yang tidak dapat dipilah-pilah yang meliputi pendidikan jasad, pendidikan ruh, dan pendidikan intelektualitas. Ketiga bentuk pendidikan tersebut tidak mungkin dan tidak akan dibenarkan pemilahannya dalam ajaran Islam. Sebagaimana telah dijelaskan, pendidikan berhubungan langsung dengan komposisi kehidupan manusia. Memilah-milah pendidikan manusia berarti memilah- milah kehidupannya.

Secara fundamental, pendidikan Islam terpadu berupaya menginternalisasikan nilai-nilai Islam (ruh Islami, jiwa Islam) melalui proses pendidikan Islam ke dalam seluruh aspek pendidikan. Tujuan utamanya adalah memadukan nilai-nilai sains dan teknologi dengan keyakinan, kesalehan dalam diri peserta didik.

3. Prinsip-Prinsip Umum Pendidikan Islam

Melihat pembahasan ini sangat luas, penulis membatasi pada prinsip-prinsip umum yang mendasari tujuan, kurikulum, metode, murid dan guru, lingkungan dan evaluasi pendidikan Islam. Tujuannya adalah mampu mendeskripsikan prinsip-prinsip umum pendidikan Islam tersebut.

a. Visi Pendidikan Islam

Pendidikan Islam yang dilakukan Rasulullah di Makkah

7 Ahmad Tafsir. Ilmu Pendidikan Dalam Perspektif Islam. (bandung : Remaja Rosda karya,1994), hlm.32 kepada para sahabat pada saat itu bertujuan membina pribadi Muslim agar menjadi umat yang berjiwa kuat dan menjadi masyarakat Islami, pendakwah (muballigh), dan pendidik yang baik. ${ }^{8}$ Kemudian setelah hijrah, pendidikan Islam mengalami perkembangan dan diarahkan, disamping membentuk kader Islam, juga diarahkan membina aspek aspek kemanusiaan dalam menjaga dan mengelola kesejahteraan alam ini. ${ }^{9}$

Visi dari pendidikan Islam adalah sesuai dengan tujuan hidup manusia, ${ }^{10}$ sebab pendidikan hanyalah sebagai media yang digunakan oleh manusia untuk memelihara keberlanjutan hidup, baik sebagai individu maupun masyarakat. Ada beberapa prinsip yang terkandung dalam tujuan pendidikan Islam, diantaranya adalah universal, ${ }^{11}$ keseimbangan dan kesederhanaan, kejelasan, realisme dan realisasi, dan dinamisme. ${ }^{12}$ b. Kurikulum Pendidikan Islam

Kurikulum merupakan bidang kajian ilmiah yang bisa dikatakan baru ada pada awal abad ke 20. ${ }^{13}$ Pada awalnya kurikulum pendidikan Islam hanya berkisar pada bidang tertentu dan ilmu-ilmu agama mendominasi dilembaga formal. Pada

8 Abudin Nata (ed.). Sejarah Pendidikan Islam, Pada Periode Klasik dan Pertengahan. (Jakarta: Rajawali Press. 2004 ), hlm. 11

9 Ibid, hlm. 11. Dalam buku Filsafat Pendidikan Islam karya Abudin Nata, beliau menjelaskan visi pendidikan Islam sesungguhnya melekat pada visi ajaran Islam itu sendiri yang terkait dengan visi kerasulan Nabi Adam sampai kerasulan Muhammad Rasulullah Saw, yakni membangun sebuah kehidupan manusia yang patuh dan tunduk kepada Allah serta membawa rahmat bagi seluruh alam. Lebih lanjut baca, Abudin Nata. Filsafat Pendidikan Islam. (Jakarta: Gaya Media Pratama. 2005), hlm. 30

10 Hal ini tercermin dalam surat al An'am ayat 162. 162. Katakanlah: Sesungguhnya sembahyangku, ibadatku, hidupku dan matiku hanyalah untuk Allah, Tuhan semesta alam.

11 Prinsip pendidikan Islam bersifat menyeluruh dan tidak kaku (rigid). Baik dalam pandangannya terhadap agama, manusia, masyarakat dan kehidupan. Agama Islam berusaha membina individu sebagaimana ia membina masyarakat dan menghargainya sekaligus. Dengan demikian, pendidikan Islam tidak bersifat ekslusif.

12 Abudin Nata (ed.). Sejarah Pendidikan Islam, hlm.11 -14

13 G. A. Beuchamp. Curriculum Theory. (Wilmeter: The Kagg Press, 1968), hlm. 26 
perkembangannya kurikulum semakin meluas dan dampak nya adalah diperlukannya prinsip-prinsip umum yang menjadi dasar penyusunan kurikulum pendidikan Islam. Diantaranya adalah ruh Islamiyah, universal, keseimbangan, sesuai dengan perkembangan psikologi, dan memperhatikan lingkungan sosial..$^{14}$

c. Metode Pendidikan Islam

Metode merupakan hal terpenting dalam proses ilmu pengetahuan dari pendidik kepada peserta didik. Sehingga terjadi proses internalisasi dan pemilikan ilmu oleh peserta didik. Pentingnya metode mengharuskan pendidik memahami proses belajar mengajar dan metodenya serta memahami syarat-syarat berlakunya proses belajar, juga prinsip-prinsip umum yang menjadi dasar bagi teori-teori dalam proses belajar mengajar. Setidaknya ada empat prinsip yang harus diketahui dalam metode pendidikan Islam. Diantaranya adalah menjaga tujuan pelajaran, kesesuaian dengan psikologi anak, memelihara tahapan kematangan, dan partisipasi praktikal. ${ }^{15}$

d. Murid dan Guru dalam Pendidikan Islam

Pola hubungan antara murid dan guru bukan sebagai 'pengajar', tapi lebih kepada 'pembimbing'. Sebab seorang pembimbing lebih cenderung berfungsi sebagai fasilitator atau petunjuk jalan ke arah penggalian potensi peserta didik. Pola hubungan tersebut dapat diambil prinsip prinsipnya, yaitu humanistik, ${ }^{16}$ kesetaraan dan demokratis. ${ }^{17}$

e. Lingkungan Pendidikan Islam

Poin ke lima ini menunjukkan pada situasi dan kondisi yang mengitari dan memiliki pengaruh terhadap perkemban-

14 Abudin Nata (ed.). Sejarah Pendidikan Islam, hlm.16-17

15 Abudin Nata (ed.). Sejarah Pendidikan Islam, hlm.18-19

16 Dalam proses belajar mengajar dominasi tidak saja pada guru atau siswa, tapi lebih kepada proses keberlangsungan belajar dengan dasar dasar kemanusiaan. Mengajar dnegan kerendahan hati dan mengarahkan sesuai dengan kecenderungan anak didik

17 Dalam prinsip ini bukan guru yang menduduki posisi lebih tinggi dibanding kan murid, tapi antara guru dan murid berada dalam posisi yang sama memiliki kesederajatan dalam proses pembelajaran. gan pribadi peserta didik. Realitanya dalam lingkungan pendidikan Islam kondisi dan situasi yang digunakan untuk proses belajar mengajar adalah di Masjid, rumah, perpustakaan, kuttab, madrasah, dan Universitas. Lingkungan lingkungan tersebut berfungsi menunjang terjadinya proses belajar mengajar dengan aman, tertib, dan berkesinambungan. ${ }^{18}$

f. Evaluasi Pendidikan Islam

Rangkaian akhir dari proses suatu pendidikan adalah evaluasi. Evaluasi dalam pendidikan Islam menggariskan tolak ukur yang serasi dengan tujuan jangka pendek dan jangka panjang. Jangka pendek dimaksud adalah membimbing manusia agar selamat di dunia dan jangka panjangnya adalah membimbing manusia untuk kesejahteraan di akhirat kelak. Dalam hal ini ada empat prinsip yang ditekan, yakni objektivitas, keadilan, kejujuran, dan keterbukaan. ${ }^{19}$

4. Konsep-konsep Dasar Pendidikan Islam Terpadu

Pendidikan merupakan lembaga utama yang memiliki peranan penting dalam membangun dan menumbuhkembangkan peradaban. Maju mundurnya peradaban ditentukan oleh pendidikan. Bahkan peradaban dan kebudayaan umat ini tidak akan pernah muncul tanpa ada lembaga yang mengarahkan manusia ke arah tersebut. Lebih jauh, pendidikan tidak hanya membangun, tapi juga memberikan pola dan model terhadap peradaban itu sendiri. Alhasil, pola dan model yang berbeda akan menghasilkan bentuk dan model yang berbeda pula. Ketika pola pendidikan menggunakan pola sekuler, mau tidak mau akan menghasilkan dan melahirkan pendidikan sekuler. begitu pula dengan pendidikan Islam akan melahirkan peradaban Islami.

Pendidikan Islam memiliki konsep-konsep dasar terpadu yang sebenarnya telah ada, namun belum teraplikasikan secara utuh. Konsep-konsep Pendidikan Islam terpadu yang dimaksud oleh penulis dibagi menjadi dua aspek besar. Aspek internal (aqidah dan pendidikan hati) dan aspek eksternal (akhlak, jasmani dan rohani, sosial, intelektual, dan seks)

18 Abudin Nata (ed.). Sejarah Pendidikan Islam, hlm. 22

19 Abudin Nata (ed.). Sejarah Pendidikan Islam, hlm. 23-26 
a. Aspek Internal (al-Awamil al-Dhakhiliyyah)

1) Aqidah

Secara etimologis (lughatan), aqidah berasal dari kata

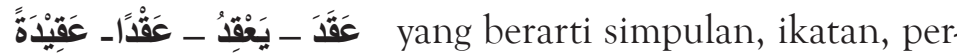
janjian dan kokoh. Setelah terbentuk menjadi 'aqidah maka diartikan sebagai iman, kepercayaan dan keyakinan. ${ }^{20}$ Relevansi antara kata 'aqdan dan 'aqidah adalah keyakinan itu tersimpul dengan kokoh di dalam hati, bersifat mengikat dan mengandung perjanjian. Meminjam pendapatnya Hassan al-Banna yang dikutip Yunahar Ilyas, secara terminologis (isthilahan) yang dimaksud dengan aqidah adalah beberapa perkara yang wajib diyakini kebenarannya oleh hati, mendatangkan ketentraman jiwa, menjadi keyakinan yang tidak bercampur sedikitpun dengan keragu-raguan. ${ }^{21}$

Aqidah merupakan pokok ajaran Islam yang berbicara tentang kepercayaan dan keyakinan yang tumbuh dan dibicarakan atas dasar ajaran agama Islam. Bisa dikatakan pula berkaitan dengan kepercayaan yang sesuai dengan kenyataan yang dikuatkan dengan dalil. ${ }^{22}$

Meminjam sistematika Hassan Al-Banna, ruang lingkup pembahasan aqidah adalah yang berkaitan dengan ilahiyat, $^{23}$ nubuwat, ${ }^{24}$ ruhaniyat, ${ }^{25}$ dan sam'iyyat. ${ }^{26}$ Kesemua

20 Syahminan Zaini. Kuliah Aqidah Islam. (Surabaya: Al-Ikhlas, t.t.h), hlm. 50. Baca juga Yunahar Ilyas. Kuliah Aqidah Islam. (Yogyakarta: Lembaga Pengkajian dan Pengamalan Islam, 2007), hlm.

21 Yunahar Ilyas, Kuliah Aqidah Islam, hlm. 1

22 Syahminan Zaini, Kuliah Aqidah Islam, hlm. 50

23 Pembahasan tentang segala sesuatu yang berhubungan dengan Ilah (Tuhan, Allah)seperti wujud Allah, nama-nama dan sifat-sifat Allah, af al Allah dan lainlain.

24 Pembahasan tentang segala sesuatu yang berhubungan dengan Nabi dan Rasul, termasuk pembahasan tentang Kitab-kitab Allah, mu'jizat, karamah dan lain lain.

25 Pembahasan tentang segala sesuatu yang berhubungan dengan alam metafisik seperti malaikat, jin, iblis, syaitan, roh dan lain sebagainya.

26 Pembahasan tentang segala sesuatu yang hanya bisa diketahui lewat sam'i (dalil naqliberupa al-Qur'an dan sunnah) seperti alam barzakh, akhirat, azab kubur, yang berkaitan dengan aqidah ini bersumber kepada alQur'an dan sunnah, apa yang tercantum di dalamnya dan apa yang disampaikan Rasulullah wajib diimani, diyakini dan diamalkan.

Adapun fungsi akidah adalah sebagai dasar, diibaratkan pondasi untuk mendirikan bangunan. Semakin tinggi bangunan yang akan didirikan, harus semakin kokoh pondasi yang dibuat. Oleh karena itu, akidah merupakan hal yang paling utama sebagai pegangan dalam meyakini sesuatu.

Pendidikan iman harus menjadi prioritas dalam pengembangan peserta didik. Dengan imam yang benar akan memiliki sikap mental positif dan baik dalam kehidupannya. Nabi Muhammad Saw memberikan pendidikan kepada para sahabat dengan memberikan penjelasan bagaimana bentuk iman kepada Allah.

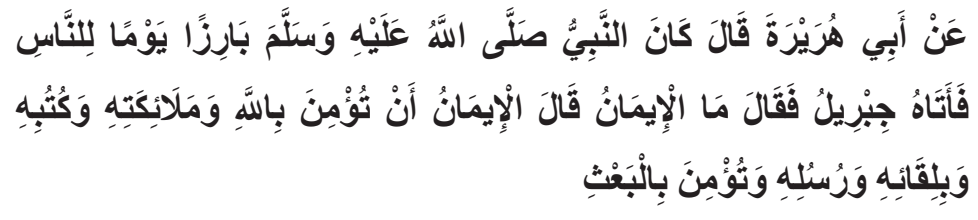

Artinya: Dari Abu Hurairah, ia berkata, pada suatu hari, Rasulullah saw. muncul di antara kaum muslimin. Lalu datang Jibril, kemudian bertanya: Apakah Iman itu? Rasulullah saw. menjawab: Engkau beriman kepada Allah, malaikat-malaikat-Nya, kitabkitab-Nya, pertemuan dengan-Nya, rasul-rasul-Nya dan kepada hari berbangkit. (Hr. Muslim)

Dari hadis tersebut dapat dipahami Nabi mengajarkan tentang tujuan pendidikan Islam. Tujuan pendidikan tersebut dalam bentuk iman kepada Allah, Malaikat, kitab, rasul, dan mempercayai hari kebangkitan. Pentingnya pendidikan iman perspektif Yusuf Qardhawi, iman merupakan benteng yang mampu menjaga seorang mukmin agar tidak berlaku kejahatan. Kehidupan yang lepas dari iman merupakan kehidupan yang tidak mengandung kebaikan, kemuliaan, dan 
rasa kemanusiaan.

Iman menjadi syarat utama dalam mencapai kesempurnaan (insan kamil), dan menjadi modal awal untuk mewujudkan prilaku yang saleh sesuai ajaran Islam. Iman memberikan ketentraman jiwa dan kedamaian tingkah laku. Karena semakin tinggi iman dan taqwa seseorang semakin tinggi pula sikap intelektual, sosial, dan lembah lembut. Selain itu, manusia yang beriman hatinya akan selalu dibimbing Allah, jiwanya tenang dalam melakukan aktifitasnya sehari-hari.

\section{2) Pendidikan Hati}

Pendidikan hati adalah bagian dari pembinaan rohani yang ditekankan pada upaya pengembangan potensi jiwa manusia agar senantiasa dekat dengan Allah, cenderung kepada kebaikan dan menjauhi keburukan. ${ }^{27}$ Berkaitan dengan hal tersebut, Rasulullah Saw bersabda.

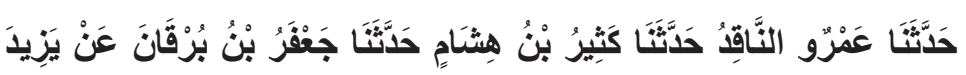

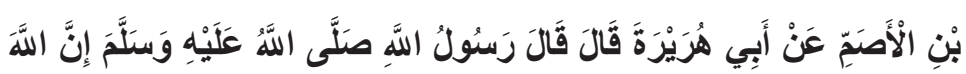

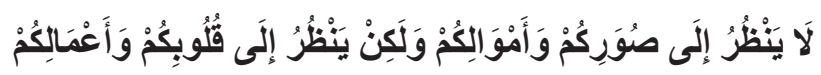

Artinya: "Telah menceritakan kepada kami 'Amru An Naqid; Telah menceritakan kepada kami Katsir bin Hisyam; Telah menceritakan kepada kami Ja'far bin Burqan dari Yazid bin Al Asham dari Abu Hurairah dia berkata; Rasulullah Saw bersabda: "Sesungguhnya Allah tidak melihat kepada rupa dan harta kalian, tetapi Allah melihat kepada hati dan amal kalian." (Hr. Muslim - No Hadis 4651)

Hadis di atas dipahami bahwa Allah menegaskan bahwa Dia lebih menghargai hati yang bersih daripada bentuk tubuh dan harta. Maka sebagai hamba Allah, tiap muslim harus berusaha mendapatkan yang terbaik di mata Allah. Hati memiliki posisi sentral dan fungsi sebagai 'nahkoda' bagi tubuh dan pikiran. Rasulullah Saw bersabda.

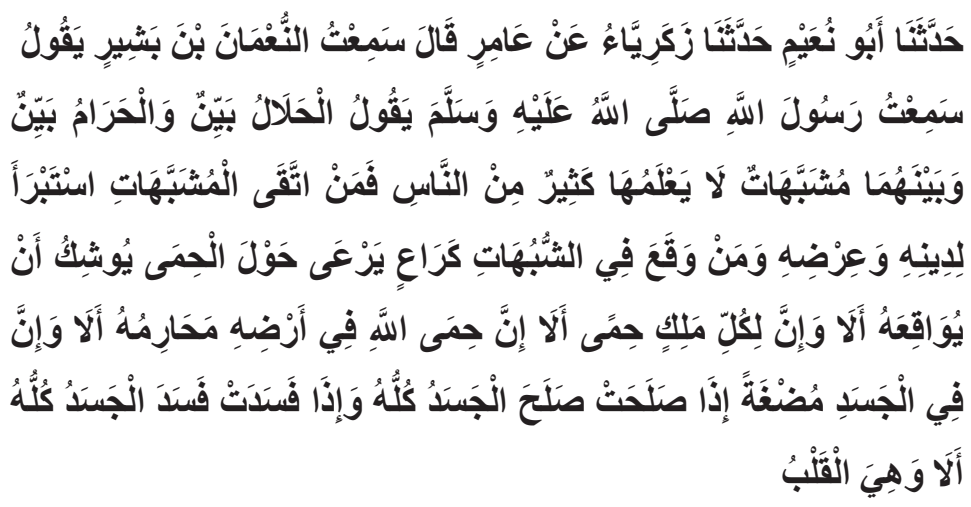

Artinya: "Telah menceritakan kepada kami Abu Nu'aim Telah menceritakan kepada kami Zakaria dari 'Amir berkata; aku mendengar An Nu'man bin Basyir berkata; aku mendengar Rasulullah Saw bersabda: "Yang halal sudah jelas dan yang haram juga sudah jelas. Namun diantara keduanya ada perkara syubhat (samar) yang tidak diketahui oleh banyak orang. Maka barangsiapa yang menjauhi diri dari yang syubhat berarti telah memelihara agamanya dan kehormatannya. Dan barangsiapa yang sampai jatuh (mengerjakan) pada perkara-perkara syubhat, sungguh dia seperti seorang penggembala yang menggembalakan ternaknya di pinggir jurang yang dikhawatirkan akan jatuh ke dalamnya. Ketahuilah bahwa setiap raja memiliki batasan, dan ketahuilah bahwa batasan larangan Allah di bumi-Nya adalah apa-apa yang diharamkan-Nya. Dan ketahuilah pada setiap tubuh ada segumpal darah yang apabila baik maka baiklah tubuh tersebut dan apabila rusak maka rusaklah tubuh tersebut. Ketahuilah, ia adalah hati." (Hr. Bukhari - No Hadis 50)

Informasi yang diperoleh dari hadis di atas adalah keadaan hati seseorang sangat menentukan semua kondisi meliputi perkataan, sikap, dan prilakunya. Dengan kata lain, jika hatinya sehat maka perkataan, sikap, dan prilakunya akan baik. Begitu pula sebaliknya, saat hatinya kotor maka perkataan, sikap, dan prilakunya akan kotor pula. 
b) Aspek Eksternal (al-Awamil al-Kharijiyyah)

1) Pendidikan Akhlak

Kata akhlak merupakan bentuk jamak dari kata khuluq. Kata khuluq bermakna budi pekerti, perangai, tingkah laku, atau tabi'at. ${ }^{28}$ Menurut al-Ghazali akhlak diartikan sebaga suatu ungkapan tentang keadaan jiwa bagian dalam yang melahirkan macam-macam tindakan dengan mudah, tanpa memerlukan pikiran dan mempertimbangkan terlebih dahulu. ${ }^{29}$ Sementara Abdul Hamid Yunus berargumentasi bahwa akhlak adalah sifat-sifat manusia yang terdidik. ${ }^{30}$

Dari beberapa pendapat tersebut, dapat dipahami bahwa akhlak bersumber dari aspek anak didik dan bisa juga dari aspek lingkungan. Jadi, perilaku baik dan buruk itu sangat bergantung pola pikir/prilaku dan lingkungan dimana ia tinggal. Nabi Muhammad Saw menyatakan pentingnya akhlak, sebab akhlak menjadi barometer dalam menentukan posisi anak didik dalam lingkungan sosial.

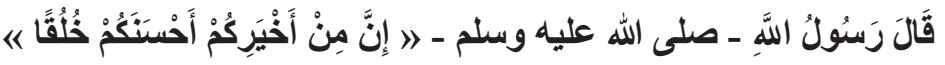

Artinya: Rasulullah Saw bersabda, sesungguhnya yang terbaik dari kalian adalah yang terbaik ahklaknya. ${ }^{31}$ (HR. Bukhari)

28 Louis Ma'luf. Qamus al Munjid. (Beirut: Al-Maktabah al-Katulukiyah, tth), hlm.

29 Al Ghazali. Ihya Ulum al Din, juz III. (Kairo: al-Masyhad al-Husain, tth), hlm. 56 30 Abdul Hamid Yunus. Da'irah al Ma'arif. (Kairo: Asy Sya'ba, tth), hlm. 56

31 Sehubungan dengan pentingnya pendidikan akhlak ini, Rasulullah Saw mengemukakan dalam beberapa hadis lain. Di antaranya:

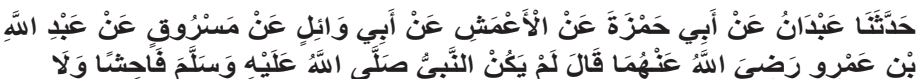

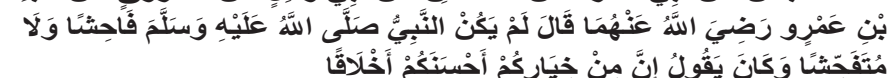

Artinya: "Telah bercerita kepada kami 'Abdan dari Abu Hamzah dari Al A'masy dari Abu Wa'il dari Masruq dari 'Abdullah bin "Amru radliallahu 'anhu berkata; "Nab shallallahu 'alaihi wasallam tidak pernah sekalipun berbicara kotor (keji) dan juga tidak pernah berbuat keji dan beliau bersabda: "Sesungguhnya di antara orang yang terbaik dari kalian adalah orang yang paling baik akhlaqnya." (HR. Bukhari - No 3295)
Dari hadis di atas dapat dipahami bahwa ahklak merupakan suatu sikap yang paling baik. Sikap baik mencerminkan pola hidup sederhana, bermartabat, dan bermoral. Sementara proses pembentukan moral merupakan upaya yang tidak mudah untuk dilakukan. Hasilnya pun, ditentukan dan dipengaruhi oleh lingkungan sekitar.

2) Pendidikan Amal Ibadah

Amal ibadah yang baik dan saleh merupakan hasil dari iman dan akhlak yang sempurna. Sehingga pendidikan amal shaleh sangat penting bagi anak didik menjadi suatu yang sangat berharga. Karena pendidikan amal iabdah mengajarkan secara langsung amalan-amalan yang diajarkan oleh al-Qur'an dan hadis Rasulullah. Banyak jenis amal ibadah yang disebutkan dalam hadis Rasulullah Saw, salah satu diantarnya adalah, pertanyaan Ibnu Mas'ud kepada Nabi Saw tentang amal yang paling dicintai Allah.

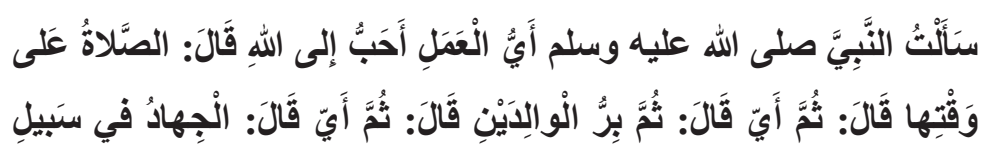

Artinya: Aku bertanya (Ibnu Mas'ud) kepada Nabi Saw, amal apa yang paling disenangi Allah, Nabi menjawab, shalat tepat waktu

Hadis selanjutnya:

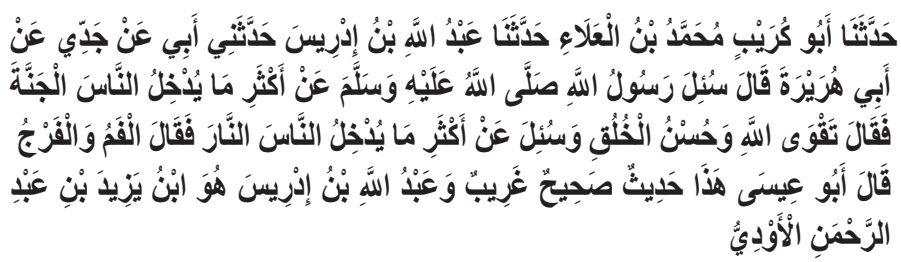

Artinya: "Telah menceritakan kepada kami Abu Kuraib Muhammad bin Al Ala", telah menceritakan kepada kami Abdullah bin Idris, telah menceritakan kepadaku bapakku dari kakekku dari Abu Hurairah ia berkata; Rasulullah shallallahu 'alaihi wasallam pernah ditanya tentang sesuatu yang paling banyak memasukkan seseorang ke dalam surga, maka beliau pun menjawab: "Takwa kepada Allah dan akhlak yang mulia." Dan beliau juga ditanya tentang sesuatu yang paling banyak memasukkan orang ke dalam neraka, maka beliau menjawab: "Mulut dan kemaluan." Abu Isa berkata; Ini adalah hadits shahih gharib. Abdullah bin Idris adalah Ibnu Yazid bin Abdurrahman Al Audi." (HR. Tirmidzi - No 1927) 
kemudian Ibnu Mas'ud bertanya, apa lagi?berbakti kepada kedua orang tuan, kemudian apa? Nabi menjawab jihad di jalan Allah.

Amal Ibadah yang dimaksud dalam hadis tersebut adalah shalat, berbakti kepada orang tua, dan jihad di jalan Allah. Masih banyak amal-amal ibadah yang di ajarkan Nabi kepada umatnya. Terakhir, tiga poin di atas kiranya menjadi pedoman bagi pendidik agar memberikan penjelasan tentang tujuan pendidikan yang sebenarnya dalam agama Islam (hadis Nabi Saw), sehingga ke depan anak didik menjadi generasi-generasi yang beriman, berkahlak mulia dan beramal ibadah kepada Allah. Iman selalu ditanamkan dalam jiwanya, ahlak mulia menjadi pakaiannya, dan amal shaleh menjadi kebutuhan dalam setiap langkah kehidupannya.

3. Pendidikan Jasmani

Menurut Sukintaka pendidikan jasmani merupakan bagian penting dari pendidikan yang mencoba mencapai tujuan untuk mengembangkan ksehatan jasmani, mental, sosial, dan emosional bagi masyarakat dengan media aktivitas jasmani. ${ }^{32}$ Pengertian tersebut mendeskripsikan bahwa pendidikan jasmani menekankan kepada proses pendidikan yang menggunakan aktivitas jasmani (badaniyah) untuk mendapatkan kesehatan/kebugaran dalam segala hal. Rasulullah Saw mengajarkan konsep-konsep dalam pendidikan jasmani. Di antaranya adalah memanah, ${ }^{33}$

32 Sukintaka. Folosof Pembelajaran dan Masa Depan Teori Pendidikan Jasmani, (Bandung: Nuansa, 2004), hlm. 16

33 Memanah pada dasarnya adalah menggunakan senjata. Pada perkembangannya senjata mengalami perubahan sesuai dengan zamannya. Sebab pada saat in senjata telah berkembang beranekaragam, maka anjuran memanah itu dapa pula bermakna mengounkan senjata modern. Anjuran Rasulullah Saw untuk melatih ketrampilan diri dengan memanah digambarkan dalam sebda beliau.

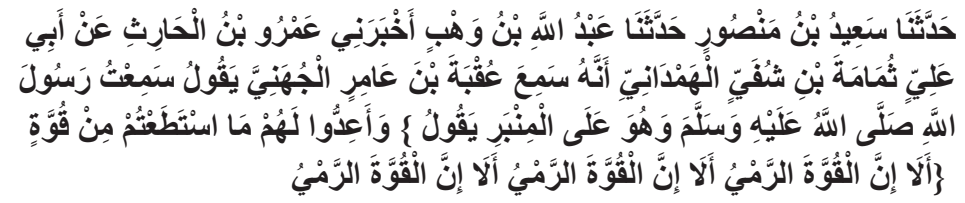

Artinya: "Telah menceritakan kepada kami Sa'id bin Manshur, telah menceritakan ke pada kami Abdullah bin Wahb, telah mengabarkan kepadaku 'Amr bin Al Harits dar Abu Ali Tsumamah bin Syufi Al Hamdani, bahwa ia mendengar 'Uqbah bin 'Amir Al berkuda, ${ }^{34}$ menjaga pola makan, ${ }^{35}$ menjaga kebersihan, ${ }^{36}$ dan lainnya. Kesemuanya bertujuan untuk menjaga dan

Juhani, berkata; saya mendengar Rasulullah Saw berada di atas mimbar berkata: "Dan persiapkan untuk mereka apa yang kalian mampu berupa kekuatan. Ketahuilah bahwa kekuatan itu adalah memanah, ketahuilah bahwa kekuatan itu adalah memanah, ketahuilah bahwa kekuatan itu adalah memanah! (HR. Abu Daud - No hadis 2153)

34 Rasulullah Saw menganjurkan kepada umatnya untuk belajar berkuda.

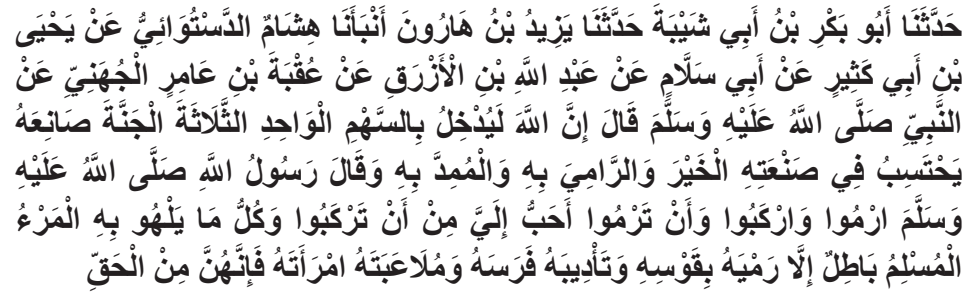

Artinya: "Telah menceritakan kepada kami Abu Bakar bin Abu Syaibah; telah menceritakan kepada kami Yazid bin Harun; telah memberitakan kepada kami Hisyam bin Ad Dastuwa ` $i$ dari Yahya bin Abu Katsir dari Abu Sallam dari Abdullah bin Azraq dari Uqbah bin Amir Al Juhani dari Nabi shallallahu 'alaihi wasallam, beliau bersabda: "Sesungguhnya Allah akan memasukkan tiga orang ke dalam surga dengan satu anak panah; pertama; pembuatnya, yang mana ia membuatnya dengan berharap kebaikan, kedua; yang membidikkannya, dan ketiga; yang membentangkannya". Dan Rasulullah Saw bersabda: 'Lemparlah dan kendarailah tunggangan, sesungguhnya melemparnya kalian itu lebih aku sukai dari pada mengendarai tunggangan, dan segala mainan apapun yang dilakukan oleh seorang muslim adalah bathil kecuali melempar anak panah, merawat kuda dan canda dengan isterinya, sungguh semuanya adalah hak." (HR. Ibnu Majah - No hadis 2801)

Menunggang kuda untuk konteks sekarang hanya sebagian orang yang mempelajarinya dan jika ditafsirkan secara umum, dapat dipahami sebagai anjuran menguasai penggunaan teknologi transportasi.

35 Pola makan seseorang sangat berpengaruh terhadap kesehatan badannya. Selain bahan makanan yang sehat, pola makannya juga harus baik, yakni teratur dan tidak berlebihan. Allah berfirman dalam surat al A'raf:31.

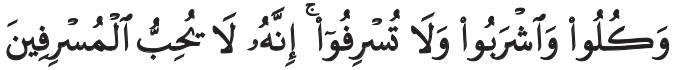

Artinya: "...Makan dan minumlah, dan janganlah berlebih-lebihan. Sesungguhnya Allah tidak menyukai orang-orang yang berlebih-lebihan."

Maksudnya adalah janganlah melampaui batas yang dibutuhkan oleh tubuh dan jangan pula melampaui batas-batas makanan yang dihalalkan.

36 Kebersihan memiliki pengaruh kepada kesehatan dan keadaan jasmani seseorang. Rasulullah Saw sangat memperhatikan persoalaan ini. Wujud perhatian beliau dapat dilihat dalam hadis berikut. 
memelihara kesehatan anggota tubuh dan lain sebagainya.

4. Pendidikan Sosial

Manusia adalah mahkluk sosial. Mereka tidak bisa hidup tanpa orang lain, maka manusia harus hidup sosial dan tidak mementingkan pribadi masing-masing. Rasulullah Saw mendidik umatnya agar memiliki sifat sosialis yang tinggi.

Pendidikan sosial yang dimaksud dalam poin ini adalah proses pembinaan dan pembelajaran kesadaran sosial, sikap sosial, dan keterampilan sosial agar anak hidup dengan baik serta wajar ditengah-tengah lingkungan dimana hidup/tinggal. ${ }^{37}$ Ada beberapa pendidikan sosial yang diajarkan Nabi, yang secara umum mewakili pendidikan sosial. Di antaranya adalah saling menolong, ${ }^{38}$ saling mencintai, ${ }^{39}$ dan men-

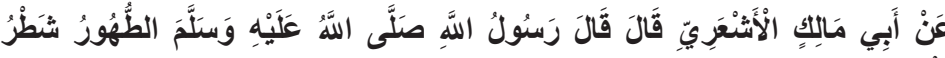

Artinya: Dari Abu Malik al-Asy'ari dia berkata, "Rasulullah Saw bersabda: "Kebersihan adalah setengah dari iman." (HR. Muslim - No hadis 328).

37 Bukhari Umar. Hadis Tarbawi (Jakarta: Amzah,2012), hlm. 55 -57

38 Anjuran Rasulullah Saw untuk saling tolong menolong tergambar dalam hadis berikut.

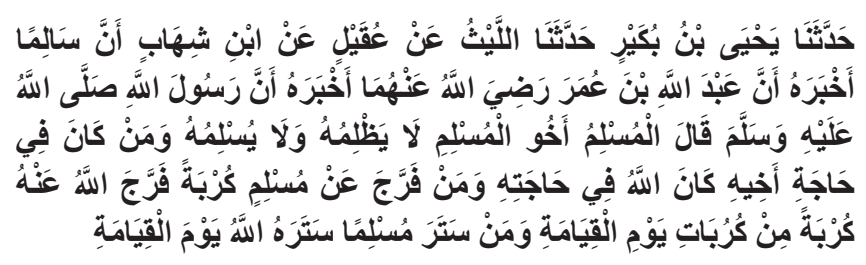

Artinya: "Telah menceritakan kepada kami Yahya bin Bukair telah menceritakan kepada kami Al Laits dari 'Uqail dari Ibnu Syihab bahwa Salim mengabarkannya bahwa 'Abdullah bin 'Umar radliallahu' 'anhuma mengabarkannya bahwa Rasulullah shallallahu 'alaihi wasallam bersabda: "Seorang muslim adalah saudara bagi muslim lainnya, dia tidak menzhaliminya dan tidak membiarkannya untuk disakiti. Siapa yang membantu kebutuhan saudaranya maka Allah akan membantu kebutuhannya. Siapa yang menghilangkan satu kesusahan seorang muslim, maka Allah menghilangkan satu kesusahan baginya dari kesusahan-kesusahan hari qiyamat. Dan siapa yang menutupi (aib) seorang muslim maka Allah akan menutup aibnya pada hari qiyamat." (HR. Bukhari -No hadis 2262)

39 Rasulullah memberikan motivasi sangat besar kepada umatnya agar mereka memiliki rasa dan prilkau yang baik. Dalam konsep pendidikan Islam terpadu, jaga persatuan. ${ }^{40}$

5. Pendidikan Intelektual

Pendidikan intelektual adalah sebuah proses meningkatkan kualitas kemampuan dalam berbagai bidang ilmu pengetahuan sehingga mampu menyesuaikan dirinya dengan kemajuan ilmu pengetahuan dalam rangka menjalankan fungsinya sebagai hamba Allah dan khalifah-Nya, untuk membangun dunia ini dengan konsep yang ditetapkanNya. ${ }^{41}$

Pendidikan intelektual mengajarkan kepada anak didik dan pendidik. Maksudnya, tidak taklid buta terhadap

hadis tersebut menggambarkan kecintaan seorang guru kepada murid dalam proses belajar mengajar. Artinya, metode yang lemah lembut dan penuh perhatian dalam mentransfer ilmu kepada muridnya. Rasulullah Saw bersabda.

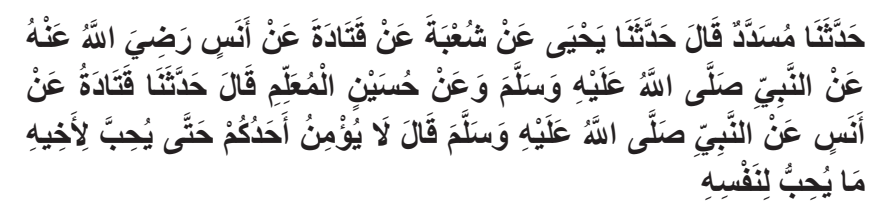

Artinya: "Telah menceritakan kepada kami Musaddad berkata, telah menceritakan kepada kami Yahya dari Syu'bah dari Qotadah dari Anas dari Nabi Saw Dan dari Husain Al Mu'alim berkata, telah menceritakan kepada kami Qotadah dari Anas dari Nabi shallallahu 'alaihi wasallam, beliau bersabda: "Tidaklah beriman seseorang dari kalian sehingga dia mencintai untuk saudaranya sebagaimana dia mencintai untuk dirinya sendiri." (HR. Bukhari - No Hadis 12)

40 Rasulullah Saw memberikan perumpamaan persatuan dengan sebuah bangunan yang saling menguatkan antara satu dengan yang lain. Perumpamaan persatuan ini mudah sekali dipahami oleh kalangan akademik maupun orang awam. Berikut hadis rasulullah Saw.

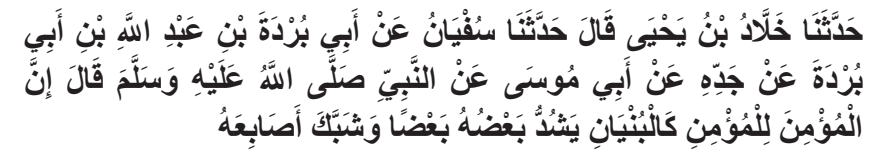

Artinya: "Telah menceritakan kepada kami Khallad bin Yahya berkata, telah menceritakan kepada kami Sufyan dari Abu Burdah bin 'Abdullah bin Abu Burdah dari Kakeknya dari Abu Musa dari Nabi Saw, beliau bersabda: "Sesungguhnya seorang mukmin dengan mukmin lainnya seperti satu bangunan yang saling menguatkan satu sama lain." kemudian beliau menganyam jari jemarinya." (HR. Bukhari - No Hadis 459)

41 Bukhari Umar. Hadis Tarbawi (Jakarta: Amzah,2012), hlm. 57 
informasi atau pendapat orang lain tanpa adanya komentar atau setidaknya memberikan tanggapan atas informasi yang datang. Rasulullah Saw mengajarkan agar umatnya tidak taklid buta, didasarkan sebuah hadis beliau.

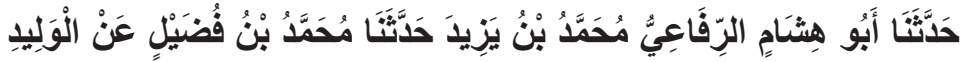

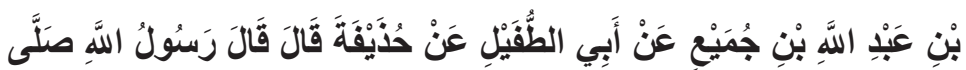

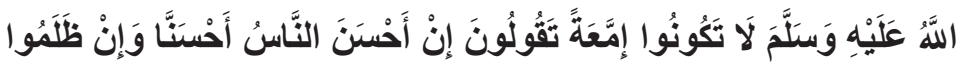

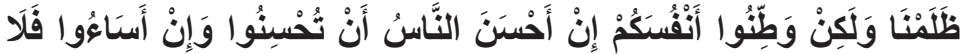

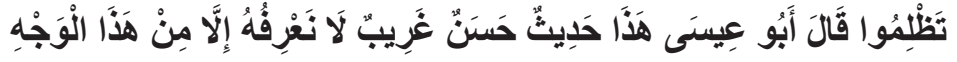

Artinya: "Telah menceritakan kepada Abu Hisyam Ar Rifa'i Muhammad bin Yazid, telah menceritakan kepada kami Muhammad bin Fudlail dari Al Walid bin Abdullah bin Jumai' dari Abu Thufail dari Hudzaifah ia berkata; Rasulullah Saw bersabda: "Janganlah kalian menjadi orang yang suka mengekor orang lain. Jika manusia menjadi baik, maka kami juga akan berbuat baik. Dan jika mereka berbuat zhalim, maka kami juga akan berbuat zhalim.' Akan tetapi mantapkanlah hati kalian, jika manusia berbuat baik kalian juga berbuat baik, namun jika mereka berlaku buruk, janganlah kalian berbuat zhalim." Berkata Abu Isa: Ini merupakan hadits hasan gharib tidak kami ketahui kecuali melalui jalur ini." (HR. Tirmidzi - No hadis 1930)

Pelajaran yang dapat dipetik dari hadis di atas adalah anjuran agar menggunakan akal/intelektual dalam membedakan antara yang benar dan yang salah atau yang baik dan yang buruk. Pelajaran lainnya adalah agar meyakini dengan keyakinan yang benar jika memang yang diyakini tersebut benar dan baik dan larangan mengikuti pendapat orang lain, apalagi mengikutinya tanpa cross-check kebenarannya.

Untuk mengasah intelektual kepada pencerahan dan hal yang baik. Jauh-jauh Rasulullah Saw telah mengajarkan metode diskusi/dialog. Sebagaimana tergambar dalam sebuah hadis.

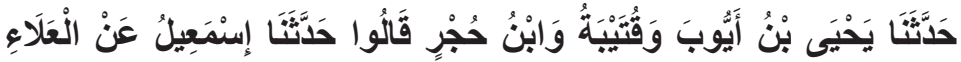

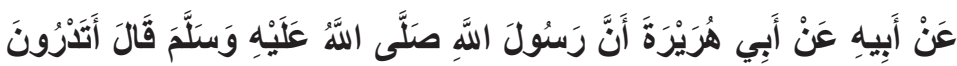

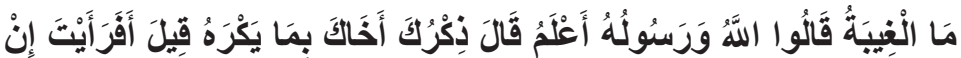

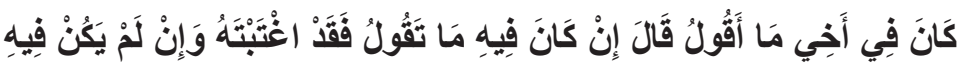 \\ فَقَََْْ بَهَتَُّ}

Artinya: "Telah menceritakan kepada kami Yahya bin Ayyub dan Qutaibah dan Ibnu Hujr mereka berkata; Telah menceritakan kepada kami Isma'il dari Al A'laa dari Bapaknya dari Abu Hurairah bahwa Rasulullah Saw pernah bertanya: "Tahukah kamu, apakah ghibah itu?" Para sahabat menjawab; 'Allah dan Rasul-Nya lebih tahu.' Kemudian Rasulullah Saw bersabda: 'Ghibah adalah kamu membicarakan saudaramu mengenai sesuatu yang tidak ia sukai.' Seseorang bertanya; 'Ya Rasulullah, bagaimanakah menurut engkau apabila orang yang saya bicarakan itu memang sesuai dengan yang saya ucapkan?' Rasulullah Saw berkata: 'Apabila benar apa yang kamu bicarakan itu ada padanya, maka berarti kamu telah menggunjingnya. Dan apabila yang kamu bicarakan itu tidak ada padanya, maka berarti kamu telah membuatbuat kebohongan terhadapnya." (HR. Muslim - No hadis 4690)

Hadis tersebut di atas menggambarkan dialog antara Rasulullah Saw dengan para sahabat. Dalam dialog tersebut, para sahabat memang menyandarkan jawabannya kepada Allah dan Rasulullah. Ringkasnya, dari dialog tersebut setidaknya membuka cakrawala berpikir para sahabat. Hal ini berbeda jika beliau langsung menjelaskan materi yang diinginkannya tanpa adanya pertanyaan.

6. Pendidikan Seks

Agama Islam sangat memperhatikan persoalan seks yang tujuannya adalah menyeimbangkan pertumbuhan sehingga pembentukannya sesuai dengan tabiat yang telah diciptakan Allah dan fitrah yang telah ditakdirkannya. ${ }^{42}$ Dengan kata lain, keseimbangan dalam segala hal merupakan salah satu bagian dari karakter Islam yang istimewa. 
Dorongan seksual yang telah diciptakan Allah dalam diri manusia menjadi sebab kelangsungan seluruh makhluk hidup. Allah menjadikan masa tertentu untuk melakukan hal ini agar manusia dapat melanjutkan generasi/keturunan.

Agama Islam memberikan kaidah-kaidah agar orang tua menjaga anaknya dari penyimpangan seksual. Diantaranya adalah:

a. Memisahkan tidur anak

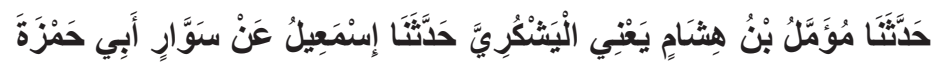

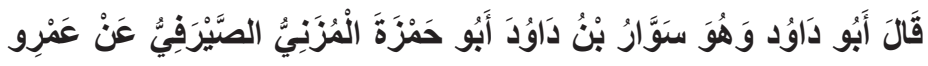

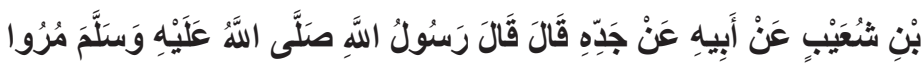

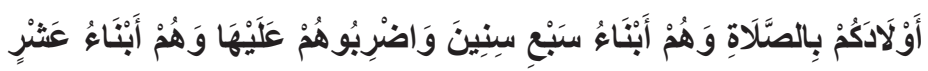

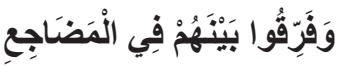

Artinya: "Telah menceritakan kepada kami $\mathrm{Mu}$ "ammal bin Hisyam Al-Yasykuri telah menceritakan kepada kami Isma'il dari Sawwar Abu Hamzah berkata Abu Dawud; Dia adalah Sawwar bin Dawud Abu Hamzah Al-Muzani Ash-Shairafi dari Amru bin Syu'aib dari Ayahnya dari Kakeknya dia berkata; Rasulullah Saw bersabda: Perintahkanlah anak-anak kalian untuk melaksanakan shalat apabila sudah mencapai umur tujuh tahun, dan apabila sudah mencapai umur sepuluh tahun maka pukullah dia apabila tidak melaksanakannya, dan pisahkanlah mereka dalam tempat tidurnya." (HR. Abu Daud - No Hadis 418)

Mengutip pendapat Suwaid, anak berumur 10 tahun harus dipisahkan, antara anak laki-laki dan perempuan. Menurutnya anak laki-laki dan perempuan harus dipisahkan dan tidak boleh tidur dalam satu selimut. Jika tidur dalam satu ranjang yang sama, maka harus dengan selimut yang berbeda. Lebih utama adalah dijauhkan/ dipisahkan antara keduanya. ${ }^{43}$

Tidur dalam satu selimut atau ranjang menyebab-

43 Muhammad Nur Abdul Hafizh Suwaid, Mendidik Anak Bersama Nabi, Panduan Lengkap Pendidikan Anak Disertai Teladan Kehidupan Para Salaf, terj. (Solo: Pustaka Arafah, 2004), hlm. 387 kan naluri seksual anak timbul dan tumbuh cepat sehingga menimbulkan berbagai indikasi penyimpangan seksual.

b. Menundukkan pandangan dan memelihara aurat

Pandangan merupakan pintu bagi anak untuk melihat dunia luar. Apa yang dilihat dan disaksikan akan tertanam dalam jiwa dan benak anak. Rasulullah Saw mengajarkan agar sejak dini anak dibiasakan menundukkan pandangan dan menutup aurat. Memberikan pemahaman kepada mereka bahwa Allah selalu mengawasi segala gerak gerik yang dilakukan. Rasulullah Saw pernah memalingkan wajah sebab melihat Fadhl bin Abbas bertatapan dengan gadis dari Khats'am saat meminta fatwa kepada beliau.

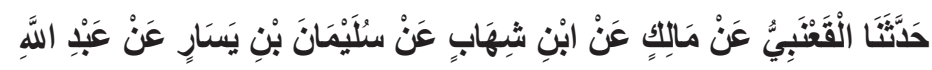

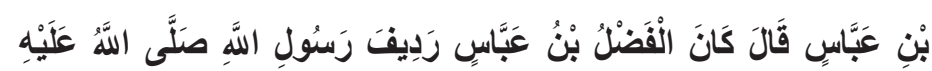

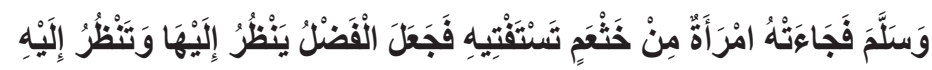

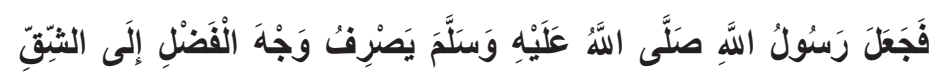

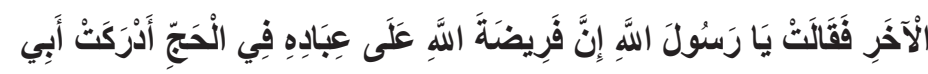

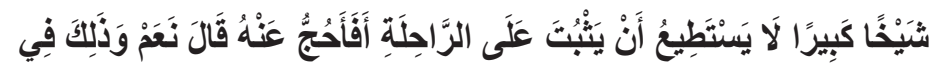
حَجَّة الْوَدَاعَ

Artinya: "Telah menceritakan kepada Kami Al Qa'nabi, dari Malik dari Ibnu Syihab dari Sulaiman bin Yasar dari Abdullah bin Abbas, ia berkata; Al Fadhl bin Abbas pernah membonceng Rasulullah Saw, kemudian datang seorang wanita dari Khats'am yang bertanya kepada beliau; dan Al Fadhl melihat kepadanya, dan wanita tersebut melihat kepadanya. Kemudian Rasulullah Saw memalingkan wajah Al Fadhl ke sisi yang lain. Wanita tersebut berkata; wahai Rasulullah, sesungguhnya kewajiban yang Allah bebankan kepada para hambaNya untuk melakukan haji telah menjumpai ayahku yang tua renta, dan tidak mampu untuk duduk di atas kendaraan. Apakah aku boleh berhaji untuknya? Beliau mengatakan: "Ya." Dan 
hal tersebut di saat terjadinya haji wada." (HR. Abu Daud No Hadis 1544)

Menundukkan pandangan terhadap aurat lawan jenis merupakan pengamalan perintah Allah Swt.

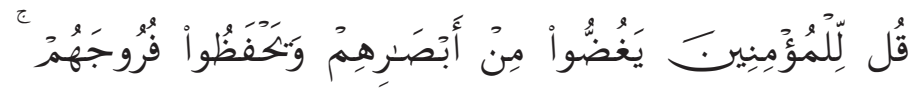

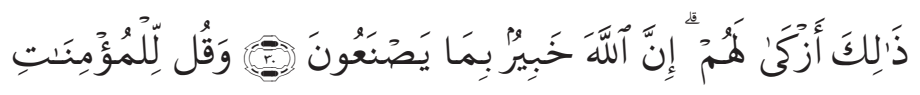

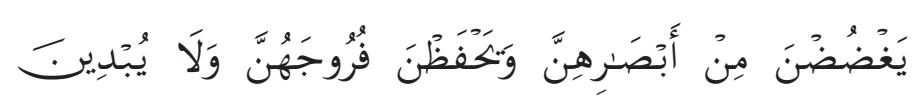

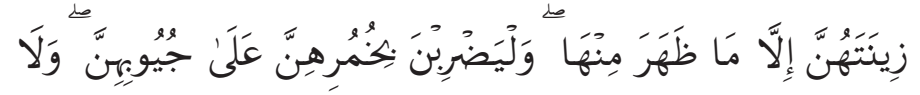

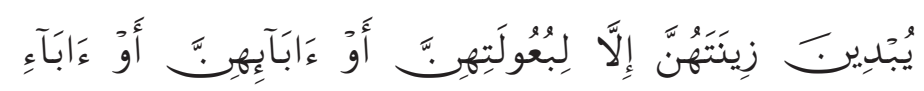

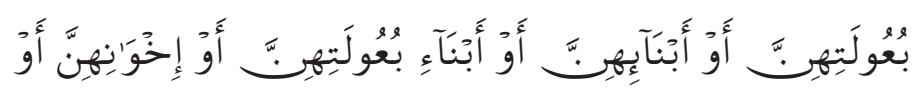

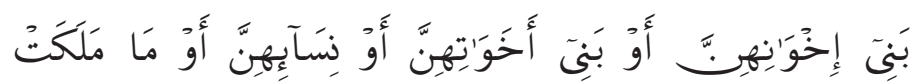

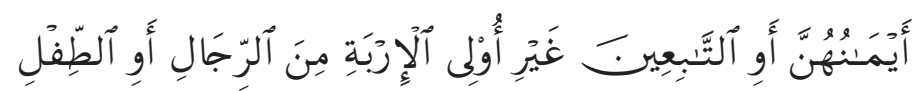

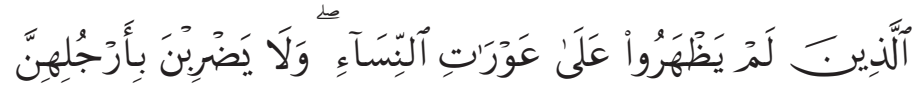

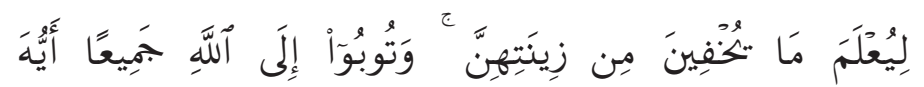

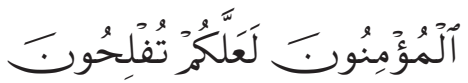

Artinya: "Katakanlah kepada orang laki-laki yang beriman: "Hendaklah mereka menahan pandanganya, dan memelihara kemaluannya; yang demikian itu adalah lebih Suci bagi mereka, Sesungguhnya Allah Maha mengetahui apa yang mereka perbuat". Katakanlah kepada wanita yang beriman: "Hendaklah mereka menahan pandangannya, dan kemaluannya, dan janganlah mereka menampakkan perhiasannya, kecuali yang (biasa) nampak dari padanya. dan hendaklah mereka menutupkan kain kudung kedadanya, dan janganlah menampakkan perhiasannya kecuali kepada suami mereka, atau ayah mereka, atau ayah suami mereka, atau putera-putera mereka, atau putera-putera suami mereka, atau Saudara-saudara laki-laki mereka, atau putera-putera saudara lelaki mereka, atau puteraputera saudara perempuan mereka, atau wanita-wanita islam, atau budak-budak yang mereka miliki, atau pelayan-pelayan laki-laki yang tidak mempunyai keinginan (terhadap wanita) atau anak-anak yang belum mengerti tentang aurat wanita. dan janganlah mereka memukulkan kakinyua agar diketahui perhiasan yang mereka sembunyikan. dan bertaubatlah kamu sekalian kepada Allah, Hai orang-orang yang beriman supaya kamu beruntung." (Qs. al Baqarah: 30-31)

\section{Analisis Konsep-konsep Dasar Pendidikan Islam Terpadu}

Konsep-konsep dasar pendidikan Islam terpadu merupakan konsep utuh dan terintegral untuk membangun peradaban masa mendatang yang cerah sesuai dengan tuntunan al-Qur'an dan sunnah. Sehingga Islam menjadi barometer pendidikan di Dunia Islam Khususnya dan manusia umumnya.

Aspek internal dalam konsep pendidikan Islam terpadu dalam bidang aqidah menekankan pada aspek keyakinan kepada Allah. Ketika keyakinan ini ditanamkan pada peserta didik sejak dini maka keyakinan tersebut akan mengakar dan berdampak pada kedekatakan/taqarrub kepada Allah dalam segala kondisi. Sebaliknya, ketika keyakinan ini tidak dikenalkan bahkan tidak ditanamkan sejak dini, maka dampaknya adalah adanya sikap dangkal terhadap tuhan, selain itu munculnya kurang keyakinan siapa sebenarnya Tuhan yang menciptakannya.

Aspek kedua adalah pendidikan hati. Pendidikan hati penekanannya pada potensi jiwa agar peserta didik senantiasa dekan dengan penciptanya, cenderung kepada yang baik dan tidak cenderung kepada hal buruk. Sebaliknya jika peserta didik tidak ditekankan kepada pendidikan hati ini, maka dampaknya adalah perkataan, sikap, dan prilakunya akan kotor bahkan berkarat.

Pada Aspek eksternal pendidikan akhlak memiliki peran sentral karena akhlak menjadi simbol dalam tatanan kehidupan bermasyarakat. Saat anak dididik dengan akhlakul karimah, maka akhlak tersebut akan terus dilaksanakan dan diamalkan dalam kehidupan sehari-hari baik kepada, teman sejawat, orang tua, bahkan dalam ke- 